Е.В. Куликова, Е.Н. Романенко, Л.К. Садыкова,

Н.И. Улендеева. Самара: ПГСГА, 2013. 124 с.

16. Шестаков С., Юрченко Е. Уравнение с параметром. М.: Слог, 1993. 107 с.

17. Островский А.И., Кордемский Б.А. Геометрия помогает арифметике. М.: Столетие, 1994. 176 с.

18. Готман Э.Г., Скопец 3.А. Решение геометрических задач аналитическим методом. М.: Просвещение, 1979. 128 с.

19. Готман Э.Г., Скопец 3.А. Задача одна - решения разные: геомет. задачи: Кн. для учащихся. М.: Просвещение, 2000. 224 с.

20. Подходова Н.С., Ложкина Е.М. Введение в моделирование. Математические модели в естествознании (биология, химия, экология): учебное пособие. СПб.: Изд-во РГПУ им. А.И. Герцена, 2009. 177 с.
21. Профессиональный стандарт. Педагог (педаго-гическая деятельность в сфере дошкольного, началь-ного общего, основного общего, среднего общего образования) (воспитатель, учитель). Утвержден приказом Министерства труда и социальной защиты Российской Федерации от 18.10.2013 г. № 544н // Российская газета - Федеральный выпуск, № 6261 (285). 18.12.2013.

22. Федеральный государственный образовательный стандарт высшего образования. Уровень высшего образования. Бакалавриат. Направление подготовки 44.03.05 Педагогическое образование (с двумя профилями подготовки). Утвержден приказом Министерства образования и науки Российской федерации от 09.02.2016 г. № 91 [Электронный ресурс] // http:/Минобрнауки.рф/документы/8073.

\title{
INTEGRATION OF KNOWLEDGE WHILE MATHEMATICAL COURSES STUDYING BY PROSPECTIVE TEACHERS OF MATHEMATICS
}

(C) 2018

Evelina Lyubov Nikolaevna, candidate of pedagogical sciences, associate professor of Physics, Mathematics and Teaching Methods Department Samara State University of Social Sciences and Education (Samara, Russian Federation)

Abstract. The paper focuses on the main directions of integration in modern education. The basis for the examples and conclusions were fundamental studies in the field of Philosophy, Pedagogy and Mathematics. Integration as a general methodological concept in the context of the paper is more concerned with the integration of knowledge in the content of the school course of Mathematics in order to recognize and operate on them in various academic disciplines and the surrounding life. As examples of integration the author gives various concepts from different branches of mathematics (straight line, proportion, symmetry), methods of solving equations and inequalities (functionalgraphic, coordinate-vector along with traditional methods), methods of proving identities and inequalities (geometric methods in Algebra and algebraic methods in Geometry). The study of mathematical content in the classroom at school should be a systematic and multifaceted process for the teacher to establish and disclose the links between different concepts, their properties, as well as methods of applying knowledge in a variety of situations. In mathematical courses and the course of Mathematics teaching methods the author offers to pay special attention to prospective teachers' ability development to consider mathematical objects from different sides, thereby establishing links between different sections of Mathematics. Various special courses (or elective courses) on relevant subjects are also an important part of prospective teachers' professional training, which can be purposefully used to expand intersubject relations. In addition, the subject of term and final papers can also be made up taking into account different interpretations of mathematical concepts and methods. The author also pays great attention to the organization of such work with students. Only free knowledge enables the teacher to form students' solid educational results at the level of knowledge and educational activities for the purpose of their further use in professional activities and in everyday life.

Keywords: modern mathematical education; integration processes in Pedagogy; integration of subject content; training of prospective teachers of Mathematics; multifunctionality of mathematical concepts; mathematical methods of solving equations and inequalities; functional-graphic method of solving equations; coordinate-vector method of solving equations.

УДК 372.87

DOI 10.24411/2309-4370-2018-14308

Статья поступила в редакцию 27.10.2018

\section{МЕТОДИКА ВЫЯВЛЕНИЯ «ДУОВЕКТОРНОЙ» ОДАРЕННОСТИ У ДЕТЕЙ 6-7 ЛЕТ В УСЛОВИЯХ ХУДОЖЕСТВЕННО-ТВОРЧЕСКОГО ПРОЦЕССА}

(C) 2018

Калинина Лариса Юрьевна, кандидат педагогических наук, ведущий научный сотрудник научно-исследовательской части

Иванов Дмитрий Викторович, кандидат психологических наук, доцент кафедры педагогики и психологии Самарский государственный социально-педагогический университет (2. Самара, Российская Федерация)

Аннотаџия. В статье рассматривается один из аспектов раннего выявления одаренности: установление взаимосвязи между ее видами. Решение проблемы авторы видят в разработке и валидизации методики, основанной на интегрированном современном научном знании - психолого-педагогическом и искусствоведческом - в области современного искусства. Данная методика, как предполагается, будет отвечать условиям экономичности и доступности в применении педагогами, работающими с детьми. Внесены уточнения в базовое для статьи понятие «одаренность». Предложен термин, характеризующий взаимосвязанное проявление 
двух видов одаренности, - «дуовекторная» одаренность. Представлена методика, направленная на поиск скрытых признаков «дуовекторной» одаренности: музыкально-математической, в области изобразительного искусства и спорта, музыкально-лингвистической. В основе данного подхода лежит представление о зависимости частоты и яркости проявлений одаренности от условий, важнейшим из которых является обогащенная разномодальным материалом для творчества эстетическая среда. При этом целесообразно приобщать детей к доступным и эстетически ценным произведениям современного искусства, к поиску нового знания теми же способами, которыми пользуются взрослые авторы XXI века. Моделируя непосредственно воспринимаемые творческие приемы и формы, ребенок осваивает мир, структурирует его нелинейно, по принципу создания ризом. В качестве «катализатора» творческой деятельности предлагается комплекс адаптированных к возрастным особенностям детей заданий-субтестов. Охарактеризована процедура проведения эксперимента в специально организованной образовательной среде - арт-мастерской. Погружаясь в атмосферу «продуктивного беспорядка», ребенок действует свободно и непосредственно, занимается неотличимым от игры творчеством, создает арт-продукт, обладающий ценностью как маркером его одаренности, а также, отчасти, художественной. Представлено содержание творческих заданий, по итогам работы над которыми заполняется диагностическая карта, являющаяся, в свою очередь, обоснованием для выводов о наличии у ребенка «дуовекторной» одаренности. На данном этапе исследования авторы подготовили методику к валидизации путем сравнения с тестами и субтестами других методик. Материалы статьи логически продолжают исследование в области поиска опорных точек для разработки индивидуальных образовательных маршрутов обучающихся, подготовки их к непрерывному образованию в течение всей жизни.

Ключевые слова: одаренность; одаренные дети; образование; творчество ребенка; синтез искусств; учебная художественно-творческая деятельность; ризома; старшие дошкольники; первоклассники; арт-мастерская; индивидуальная образовательная траектория; современное искусство; арт-композиция.

В условиях модернизации образования педагогам необходимо знать «особенности детей, одаренных в избранной области деятельности, специфику работы с ними» [1], чтобы на основе этого знания «проектировать и корректировать индивидуальную образовательную траекторию обучающегося» [2].

При этом проблема одаренности - одного из личностных качеств, на которые должны опираться учителя, воспитатели, педагоги дополнительного образования в определении стратегии и тактики сопровождения ребенка по образовательному маршруту, остается не решенной в ряде аспектов. Требует уточнения само понятие «одаренность», так как появилось много новых публикаций, материал которых проливает свет на ранее остававшиеся без внимания вопросы. На данной основе можно будет конкретизировать методику ее выявления.

Феномен одаренности рассматривали Т. Балчин, Д.Б. Богоявленская, Э. Виннер, Д. Даи, Х. Гарднер, А. Гессер, Дж. Гилфорд, Ф. Горовиц, Дж. Дрейк, С. Кауфман, Т. Кеттлер, Д.К. Кирнарская, Дж. Мартино, Ф. Монкс, Дж. Рензулли, С. Рейс, Д. Симонтон, Р. Стернберг, М. Сторфер, Дж. Фельдьюсен, С. Филлипсон, Дж. Фильд, К. Хеллер, В.Д. Шадриков, К. Эрикссон и др. Благодаря их исследованиям, мы видим поле научного знания в данной области, а также информационные лакуны, которые предстоит заполнить.

Интерес к изучению феномена повышается в периоды развития общества, как ответ на новые вызовы. Так, «кубическая модель интеллекта» была предложена Дж. Гилфордом в 1959 году [3], согласно запросам научно-технической революции к увеличению ресурса специалистов, творчески мыслящих и способных побеждать в конкурентной борьбе. Данная модель присутствует во многих работах по исследованию одаренности в качестве явной или подразумеваемой исходной точки, от которой идет развитие идеи зависимости высоких достижений от индивидуальных (природных) предпосылок.

Дж. Рензулли создал концепцию, отражающую идею взаимодействия трех групп человеческих качеств: превышающих средний уровень интеллекту- альных способностей, высокой увлеченности выполняемой задачей и высокого уровня креативности [4]. Чтобы одаренность проявилась, необходимо взаимодействие между этими группами (схематично изображаемыми в виде колец). При этом ведущей причиной идентификации ребенка как одаренного является высокая продуктивность при решении теоретических или практических задач [5]. Продолжая работу в русле данной теории, научная школа Дж. Рензулли приходит к выводам о том, что система выявления одаренности у детей должна быть экономичной и гибкой, ориентировать на внимательное отношение педагога к «одаренному поведению» обучающегося в различных областях: музыки, изобразительного искусства, театра, технологий, математики и других [6]. То есть найден ориентир создания системы выявления признаков одаренности - интеграция образовательных областей. Практическим результатом исследований является разработка и внедрение электронного многокритериального профиля, на основе которого ребенку дается характеристика с точки зрения его одаренности (Дж. Фильд [7], Дж. Рензулли и С. Рейс [8]).

Европейские ученые следуют по пути дополнения «трехкольцевой» схемы новыми аспектами. В результате появилась т.н. «мультифакторная модель одаренности». К.А. Хеллер рассматривает взаимодействия:

- когнитивной одаренности (интеллектуальной, творческой, социальной и др.);

- личности (мотивации, интересов, Я-концепции);

- социальной среды (климата семьи и школы, условий обучения, отношений со сверстниками).

Таким образом, акцент поставлен на том, как одаренность существует во внешнем мире. Продуктом интеграции названных компонентов являются высокие индивидуальные достижения ребенка. В составе одаренности ученый исследовал: интеллектуальные способности, креативность, социальную компетентность, личностные особенности (включая мотивацию достижения, преодоление стресса, стратегии работы), достижения (в естественных науках, искусстве, спорте, других областях) и факторы среды. 
Д. Фельдхузен и С. Ховер считают: необходимо выделять в структуре ядра одаренности Я-концепцию [9]. Ф. Монкс, И. Ипенбург вместо термина «интеллектуальные способности» предложили другой, не сконцентрированный на деятельности интеллекта, - «исключительные способности»; три пересекающиеся окружности они разместили внутри микросредового треугольника «семья - школа - сверстники» [10].

Отечественная наука тоже внесла свой вклад в теорию одаренности. Психологи Ю.Д. Бабаева [11], А.И. Савенков [12] обратили внимание, что одаренность динамична, находится в непрерывном становлении. К концу XX века утвердилось мнение о том, что потенциальные предпосылки к достижениям в разных видах деятельности присущи многим детям, но реальные незаурядные результаты демонстрирует значительно меньшая их часть [13]. В «Рабочей концепции» приводится следующее определение: «одаренность - это системное, развивающееся в течение жизни качество психики, которое определяет возможность достижения человеком более высоких, незаурядных результатов в одном или нескольких видах деятельности по сравнению с другими людьми» $[14$, c. 8]. Данный подход, с его отсутствием конкретики, ориентирован на понимание феномена одаренности, в определенном смысле более гуманное, по сравнению с США и Европой, так как признаются равными возможности всех детей. Акцент не ставится на ограничениях развития, которые «предписаны» наследственностью (американская модель), материальным и социальным положением (европейская модель).

Среди общих признаков одаренности ученые называют:

- умственную работоспособность;

- активность;

- хорошую память;

- ориентацию на творческое преобразование действительности;

- увлеченность;

- интерес ко всему универсальному;

- любознательность;

- исследовательское поведение;

- настойчивость в достижении самостоятельно поставленной цели (Ф. Горовии [15], С. Кауфманн и Р. Стернберг [16], Т. Балчин [17], Д. Даи [18], E.Б. Kau [19]).

Признаки специализированной одаренности рассматриваются как достижения выше среднего уровня в одной конкретной сфере, решение любых проблем в контексте ее специфики (Х. Гарднер [20], Д. Мэтьюз и К. Фолсом [21]).

Для исследований одаренности были созданы многочисленные диагностические методики. Среди них:

- тест креативности Е.П. Торренса [22], тест одаренности к изобразительной деятельности Дж. Дрейк и Э. Виннер [23], тест «Домик» Н.И. Гуткиной [24] (используются для выявления одаренности в области изобразительного искусства);

- тест на спортивную (двигательную) одаренность И. Богдановой [25], тесты для отбора футболистов М.С. Бриля [26];

- тесты музыкальных способностей В.П. Анисимова [27], тест вербального мышления Й. Йырасека [28];
- методика МЭДИС для экспресс-диагностики интеллектуальных способностей детей 6-7-летнего возраста (И.С. Аверина, Е.И. Шабанова, Е.Н. Задорина), в которой присутствует, в числе прочих, 4-й субтест «Выявление математических способностей» [29].

Существующие методики направлены на выявление отдельных видов одаренности или ее общих признаков, не затрагивая сочетания, находящиеся между этими крайностями. В большинстве случаев исследование требует значительных затрат времени, а педагоги затрудняются использовать эти методики без помощи психолога. Поэтому методическое обеспечение раннего выявления одаренности нельзя считать достаточным.

Обзор приведенных источников позволил выделить вопрос взаимосвязи отдельных видов одаренности как малоизученную область. Далее мы обратимся к научным публикациям последних лет, чтобы проверить гипотезу о том, что взаимосвязь видов одаренности обоснована в характеристиках данных видов.

К 2014 г. К.А. Эрикссоном [30] и его научным коллективом [31] были получены новые данные о том, что одаренность идентифицируется педагогами в зависимости от условий, более или менее благоприятных для ее проявления обучающимися, а также воспринимается в виде качества, свойственного детям с лучшей мотивационной поддержкой, доступом к лучшим учебным ресурсам. По результатам исследований К.А. Эрикссон пришел к выводу: постоянное отслеживание продуктивности ребенка в спорте, шахматах, музыке, балете необходимо для установления ее связи с творческими достижениями в области науки и искусства. Водораздел между видами одаренности как требующими разного подхода к их изучению не проводится. Напротив, перечисление в одном ряду сближает их.

А.И. Савенков обратил внимание, что одаренность очень редко проявляется только в одной сфере деятельности. Следовательно, обнаружение устойчивой связи между одаренностью в конкретных сферах может открыть до сих пор неизвестные перспективы личностного и профессионального развития ребенка. Ученые, занимающиеся проблемой одаренности, предлагают характеристики ее видов, в некоторых пунктах практически совпадающие.

Во-первых, назовем работы, посвященные художественной одаренности. А.А. Адаскиной [32], А.А. Никитиным [33], А.А. Мелик-Пашаевым, 3.Н. Новлянской, А.А. Адаскиной, Н.Ф. Чубук [34] представлена концепция базовых составляющих детской художественной одаренности, включая:

- целостно-личностную характеристику ребенка, выраженную в эстетическом отношении к действительности;

- креативность;

- владение формой.

Д.К. Кирнарская [35] характеризует музыкальную одаренность, выделяя в ее структуре:

- аналитический слух (операционную способность);

- интонационный слух (мотивационную способность);

- архитектонический слух (эстетическую способность).

Концепцию математической одаренности, предложенная B.A. Тестовым [36], основанная на при- 
знании ядром данного феномена математических способностей:

- алгоритмических;

- комбинаторных;

- геометрических.

Представление о спортивной одаренности И.Ю. Соколик [37] и В.A. Сальникова [38] основано на том, что данное качество является целостным; это системное сочетание природных задатков и двигательных способностей. Корреляция между спортивными достижениями и физическими данными, как пишут исследователи, подтверждена статистикой.

Характеризуя лингвистическую одаренность, B.M. Панфилова [39] рассматривает ее не как целостное явление, а как комплекс способностей, обеспечивающих успешность в изучении иностранных языков.

Поскольку нас интересует наличие аналогий в проявлении разных видов одаренности, приведем их.

Первую пару образуют чувствительность к музыкальным структурам (тональности, гармонии, ритму) и чувствительность к вычисляемым комбинациям отношений в математике (Э. Виннер и Дж. Мартино [40], Д.К. Кирнарская и Э. Виннер [41], Х. Гарднер). Как и композитор, человек с математическим типом мышления в воображении анализирует ту или иную конфигурацию, но не звуков, а визуальных объектов. Процесс решения математической задачи аналогичен сочинению музыкального произведения (В.А. Тестов). Такое качество математического (алгоритмического) мышления, как формулировка и применение алгоритмов, близко исполнительским, импровизаторским навыкам музыканта (А.А. Столяр [42], А.А. Никитин [43], Э.Ж. Гингулис [44]).

Вторая пара: одаренность в области изобразительного искусства и спорта. Объединяющим началом служит сходство видео-моторной координации как базового признака художественно-изобразительной одаренности (Э. Виннер и Дж. Мартино, Е.Ф. Сафроненко [45]) и точности, организованности, скоординированности, скорости движений спортсмена (Х. Гарднер [46], Т. Ранкинен и К. Бочард [47]).

Третья пара - сходство проявлений музыкальной и лингвистической одаренности в процессе распознавания коммуникативных архетипов (Д.К. Кирнарская), а также в точном воспроизведении мелодии речевой интонации, последовательности интонаций (О.Н. Игна [48]).

Таким образом, некоторые виды одаренности представлены как связанные между собой; есть основания считать, что они должны проявляться вместе. Далее мы будем использовать термин «дуовекторная одаренность» (от лат. duo - два, vector - везущий, несущий), имея в виду внутренний ресурс человека, являющийся предпосылкой успешной деятельности в двух различных сферах. Дуовекторная одаренность - это аспект одаренности, не совпадающий с ее общими и специализированными признаками, поэтому требующий особого подхода к ее изучению и соответствующей диагностики. На основе этого уникального таланта, в котором соединяются музыкальная и математическая, художественно-изобразительная и спортивная, музыкальная и лингвистическая одаренность, образовательная траектория обучающегося может выстраиваться по направлению к новым спе- циальностям и сферам деятельности, которые в будущем будут очень востребованными.

Проектируя методику выявления «дуовекторной» одаренности, мы придерживались принципа о стирании различий между образовательными системами, обусловленном глобализацией. То есть педагоги, работающие с детьми, могут заимствовать технологии, апробированные в художественном образовании взрослых («adult art education», термин М. Такахаши [49]). На интерактивном, динамичном, мультидисциплинарном образовательном пространстве открытие новых форм и микроформ деятельности обучающихся присутствует всегда. Формотворчество свойственно самим детям, которые только что поступили или скоро будут поступать в школу. Кратчайший путь к познанию им открывает знакомство с тем, как исследует мир современное искусство, с его «плодотворным беспорядком» (термин У. Эко [50]), условностью границ между музыкой, рисунком, стихотворением, танцем. Действуя «как Современный Автор», ребенок находится в условиях, благоприятных для проявления природной одаренности, причем не только в одной, но и в двух сферах одновременно. Его конкретные действия состоят в создании композиций из доступных ему материалов, предметов и природных средств выразительности - движений, голоса, «звучащих жестов».

Современное искусство создает вокруг нас ранее не существовавшую среду, где интегрируются художественное и нехудожественное. Его воздействие на человека, а тем более ребенка, бывает очень сильным. Особенно перспективно, как мы полагаем, использовать ресурс современного искусства в выявлении одаренности. Создавая в условиях «плодотворного беспорядка» «ризомы» (термин Ж. Делёза и Ф. Гваттари [51]) - художественные тексты, изменяющиеся и противоречивые, как живой организм, дети находят смысл того или иного явления, события. Деятельность «от имени Современного Автора» требует напряженности в воплощении образов, «сферического» повествования (А. Цеплитис [52; 53]), не линейного, а имеющего «сетевую» природу (Е.Ю. Сокрута [54]). Причем композиции-ризомы, созданные ребенком, вплетаются в ризому «единого русского текста» (термин Н.Б. Маньковской [55]), представляющую собой квинтэссенцию нашей национальной идеи. Одаренность, которая проявилась у 6-7-летнего ребенка, естественным образом будет развиваться в киберпространстве XXI века, достигая масштабов «ризомоподобного обучения». Согласно концепции И.М. Елкиной, это образовательная траектория, позволяющая «искать и находить знание, исследуя это пространство, двигаясь вдоль уже существующих и создавая новые связи внутри контента или с другими участниками сообщества» [56]. Исследователь полагает, что «ризомоподобное обучение» особенно продуктивно в познании природы, связей между явлениями для тех, кто только начинает осваивать мир, то есть в дошкольном и начальном образовании.

Для более полного представления об одаренности, которое будет опираться на современное знание, теоретические рассуждения необходимо проверить на практике. Методика «Искусство+» для выявления «дуовекторной» одаренности, которую мы разрабо- 
тали, доступна педагогам, экономична по времени. Она представляет собой часть диагностического инструментария, в который входят также названные выше тесты Е.П. Торренса, Дж. Дрейк и Э. Виннер, Н.И. Гуткиной, И. Богдановой, М.С. Бриля, В.П. Анисимова, Й. Йырасека и 4-й субтест методики МЭДИС.

Новизна методики заключается в ее содержании, направленном на вовлечение ребенка в творческую деятельность по принципам современного искусства, не ограничивающим авторов в выборе средств выразительности, способов освоения «плодотворного беспорядка». Действия и арт-продукт увлеченного художественным творчеством ребенка указывают на одаренность [57], «маркируя» ее признаки.

Возможность валидизации заданий-субтестов подтверждена соответствиями:

- субтест «Живой орнамент» (одаренность в области изобразительного искусства и спорта) / тесты Е.П. Торренса, Дж. Дрейк и Э. Виннер, Н.И. Гуткиной, И. Богдановой, М.С. Бриля;

- субтест «Сигналы с другой планеты» (музыкальная и лингвистическая одаренность) / тесты В.П. Анисимова, Й. Йырасека;

- субтест «Музыка чисел» (музыкальная и математическая одаренность) / тесты В.П. Анисимова и 4-й субтест методики МЭДИС.

Для второго и последующих контрольных срезов задания-субтесты разрабатываются по тем же принципам, но материал варьируется, обновляется.

К субтестам прилагается диагностическая карта. Если анализ данных показывает частоту и стабильность проявления ребенком одаренности в двух областях, объединенных субтестом, диагностируется дуовекторная одаренность [58]. Сопоставляя данные, полученные в результате апробации методики «Искусство+», с данными, полученными по другим методикам из диагностического комплекса, можно найти подтверждения ее валидности.

Использование нашей методики не приводит к скованности ребенка во время тестирования, а, наоборот, стимулирует его творчество. Задания-субтесты предполагают, что 6-7-летний автор будет импровизировать движения, стихи, музыкальные ритмы и мотивы, рисовать. Каждое из заданий служит «катализатором», активизирующим творческий процесс. Как и в современном искусстве, границы между видами творчества, художественным и нехудожественным в процессе творчества ребенка отсутствуют. Арт-продукт в данном случае - ризома, элементы которой объединены лишь выбранным ребенком смысловым центром.

Диагностическая процедура осуществляется в обстановке специально созданного педагогом «плодотворного беспорядка» с множеством подходящих для творчества ребенка предметов и материалов. В процессе художественных опытов маленький автор непроизвольно использует виды деятельности, которые обладают наибольшим взаимным притяжением именно для него; проявляет необычное поведение; создает оригинальный продукт; соединяет «несоединимое». Эти действия мы рассматриваем как маркеры одаренности, позволяющие детализировать ее признаки у каждого из детей.

Задания-субтесты предлагаются ребенку незаметно для него, как часть интегрированного занятия по музыке, изобразительному искусству, танцу, театру. Действуя как «Современный Автор», ребенок учится цитировать, создавать ризомы, постигает «изнутри» сущность искусства XXI века. Выполняется по одному субтесту на каждом занятии, что требует не более 20 минут.

В ходе выполнения ребенком заданий-субтестов педагог обращает внимание и отмечает в диагностической карте: уровень выполнения задания (от 0 до 3 баллов); факты объединения в одной композиции двух видов деятельности (музыкальной и математической, художественно-изобразительной и спортивной, музыкальной и лингвистической/речевой); обоснованность выбора материала замыслом ребенка; удачные попытки создания целостного художественного образа, выбора названия композиции.

Охарактеризуем процедуру диагностики на примере выполнения субтестов «Живой орнамент» (табл. 1) и «Сигналы с другой планеты» (табл. 2). Третий тест - «Мелодия чисел» - представлен нами в докладе «Раннее выявление одаренности: методика "Искусство+"» на Международной научно-практической конференции «Искусство и художественное образование в контексте межкультурного взаимодействия» (Казань, 12 октября 2018 г.) и в одноименной статье, опубликованной по итогам слушаний.

Если ребенок использовал для создания орнаментов предметы, предполагающие движение и отразил то, что они движутся, в орнаменте, то в диагностической карте делается отметка: «в) использованы предметы, предполагающие движение, и отражено то, что они движутся (дуовекторная - в области изобразительного искусства и спорта - одаренность)».

Критерии оценки уровня выполнения задания (деятельности ребенка):

одаренность в области изобразительного искусства

- высокий уровень (3 балла) - ребенок проявляет внимание к окружающим предметам и к орнаментам, демонстрируемым педагогом, самостоятельно выбирает предметы, подходящие для создания орнамента; дает оценку выбранным предметам с точки зрения реализации его замысла; создает орнамент из предметов быстро, самостоятельно; варьирует способы комбинирования элементов будущей арт-композиции; арт-композиция отличается оригинальностью, т.е. не похожа на работы других детей и произведения искусства; предметы в орнаменте расположены ровно по линии; линия орнамента почти не отклоняется от заданного направления;

- средний уровень (2 балла) - ребенок проявляет внимание к окружающим предметам и к орнаментам, демонстрируемым педагогом, с незначительной помощью выбирает предметы, подходящие для создания орнамента, и дает оценку выбранным предметам с точки зрения реализации его замысла; 1-2 раза при создании орнамента останавливается и обращается за помощью к педагогу; использует только один вариант комбинирования элементов будущей арт-композиции; арт-композиция отчасти напоминает работы других детей или уже известные ребенку произведения искусства; есть небольшие отклонения в орнаменте от расположения ровно по линии; сама линия орнамента немного отклоняется от заданного направления; 
- низкий уровень (1 балл) - ребенок отвлекается при восприятии окружающих предметов и орнаментов, демонстрируемых педагогом; затрудняется в выборе предметов, подходящих для создания орнамента, и в их оценке с точки зрения реализации его замысла; при создании орнамента несколько раз останавливается и обращается за помощью к педагогу; использует только один вариант комбинирования элементов будущей арт-композиции; арт-композиция явно похожа на работы других детей или известные ребенку произведения искусства; есть значительные отклонения в орнаменте от расположения ровно по линии; линия орнамента заметно отклоняется от заданного направления;

- невыполнение задания оценивается в 0 баллов.

спортивная одаренность

- высокий уровень (3 балла) - ребенок самостоятельно создает орнамент из повторяющихся движений, соответствующих форме фигур орнамента округлых или угловатых, узкого или широкого диапазона; выполняет движения «живого орнамента» с ускорением, сохраняя их одинаковыми; передает движения орнамента в игре-загадке так, что другие дети и педагог правильно определяют, какой именно; самостоятельно создает собственный орнамент из предметов спортивного назначения;

- средний уровень (2 балла) - ребенок с помощью педагога создает орнамент из повторяющихся движений, соответствующих форме фигур орнамента; незначительно меняет движения «живого орнамента» при ускорении; передает движения орнамента в игре-загадке так, что другие дети и педагог не сразу, а с помощью уточняющих вопросов определяют, какой именно; с незначительной помощью педагога создает собственный орнамент из предметов спортивного назначения;

- низкий уровень (1 балл) - фигуры орнамента, созданного ребенком, мало соответствуют орнаменту-образцу; при ускорении движения «живого орнамента» меняются почти до неузнаваемости; передает движения орнамента в игре-загадке так, что другие дети и педагог даже с помощью уточняющих вопросов не определяют, какой именно орнамент имел в виду ребенок-автор; с помощью педагога создает собственный орнамент из предметов спортивного назначения;

- невыполнение задания оценивается в 0 баллов.

таблица 1 - Деятельность педагога и ребенка в процессе выполнения субтеста «Живой орнамент»

\begin{tabular}{|c|c|}
\hline Деятельность педагога & Деятельность ребенка \\
\hline Предлагает ребенку сделать небольшую паузу в занятии и поиграть. & $\begin{array}{l}\text { Проявляет внимание } \\
\text { к предложению педагога. }\end{array}$ \\
\hline $\begin{array}{l}\text { Объясняет суть игрового задания: «Ты видишь вокруг самые разные предме- } \\
\text { ты. Некоторые из них - по одному, других несколько, но они расположены в } \\
\text { беспорядке. Если сложить одинаковые предметы рядом, получается орна- } \\
\text { мент». } \\
\text { Демонстрирует примеры «орнаментов» из различных предметов. } \\
\text { Предлагает посмотреть, как можно составить линейный орнамент из банок с } \\
\text { консервами - работа Энди Уорхолла «Тридцать две банки супа, растений, жи- } \\
\text { вотных - презентация работ чешского художника и дизайнера Альфонса Му- } \\
\text { хи, велосипедов. } \\
\text { Задает вопросы: «Какой из орнаментов понравился тебе больше всех?», «По- } \\
\text { чему именно этот?». }\end{array}$ & $\begin{array}{l}\text { Проявляет внимание } \\
\text { к окружающим предметам, } \\
\text { орнаментам из предметов. } \\
\text { Выбирает наиболее понра- } \\
\text { вившееся изображение. } \\
\text { Оценивает его эстетическую } \\
\text { привлекательность, исполь- } \\
\text { зуя соответствующий воз- } \\
\text { расту словарный запас. }\end{array}$ \\
\hline $\begin{array}{l}\text { Предлагает создать орнамент из повторяющихся движений, соответствующих } \\
\text { форме фигур орнамента, который понравился ребенку (например, орнамент из } \\
\text { банок супа - округлые компактные движения кистями рук; черепахи - мед- } \\
\text { ленные и «неуклюжие» покачивания руками, разведенными в стороны и за- } \\
\text { кругленными; рыбы - гибкие движения корпуса, как при плавании; велосипе- } \\
\text { ды - движения ногами как бы нажимая на педали велосипеда). }\end{array}$ & $\begin{array}{l}\text { Создает орнамент } \\
\text { из движений. }\end{array}$ \\
\hline $\begin{array}{l}\text { Предлагает выполнить движения «живого орнамента» с ускорением, под } \\
\text { ускоряющуюся музыку. Внимание обращается на то, что вместе с темпом ме- } \\
\text { няется художественный образ. }\end{array}$ & $\begin{array}{l}\text { Выполняет } \\
\text { «живой орнамент» } \\
\text { с ускорением. } \\
\end{array}$ \\
\hline $\begin{array}{l}\text { Предлагает передать движениями один из орнаментов, находящихся в арт- } \\
\text { мастерской, так, чтобы другие дети и сам педагог могли определить, какой } \\
\text { именно (игра-загадка). } \\
\text { Называет, к какому орнаменту относится двигательная импровизация ребенка. }\end{array}$ & Выполняет задание педагога. \\
\hline $\begin{array}{l}\text { Предлагает ребенку создать собственный орнамент, по образцу понравивше- } \\
\text { гося, из доступных предметов, изображений: «Ты видишь вокруг разные } \\
\text { предметы. Подумай, можно из них составить твой собственный орнамент? } \\
\text { Фантазируй! Если материалов для творчества недостаточно, почему бы не ис- } \\
\text { пользовать движения своего тела, выразительные жесты и позы... Например, } \\
\text { как у этого футболиста, встречаюеего зрителей перед матчами на стадионе } \\
\text { «Камп Ноу» в испанском городе Барселоне». } \\
\text { Если ребенок выбрал орнамент с велосипедами и создал собственный орна- } \\
\text { мент из предметов спортивного назначения, в диагностической карте по вто- } \\
\text { рому заданию делается отметка «ДА». }\end{array}$ & $\begin{array}{l}\text { Создает орнамент, } \\
\text { демонстрирует } \\
\text { свою работу педагогу. }\end{array}$ \\
\hline $\begin{array}{l}\text { Фотографирует «живые» орнаменты, созданные детьми, размещает фото в } \\
\text { приложении к диагностической карте. }\end{array}$ & $\begin{array}{l}\text { Участвует } \\
\text { в создании фотографий. }\end{array}$ \\
\hline
\end{tabular}


Калинина Л.Ю., Иванов Д.В.

Методика выявления «дуовекторной» одаренности у детей 6-7 лет..

13.00.00 - педагогические науки

Таблица 2 - Деятельность педагога и ребенка в процессе выполнения субтеста «Сигналы с другой планеты»

\begin{tabular}{|c|c|}
\hline Деятельность педагога & Деятельность ребенка \\
\hline Предлагает ребенку участвов & $\begin{array}{l}\text { Проявляет внимание } \\
\text { к предложению педагога. }\end{array}$ \\
\hline
\end{tabular}

Объясняет суть игрового задания: «Представьте, что по Интернету, радио, телевидению объявили о сигналах от инопланетян. Записать их не успели, но один из наблюдателей изобразил эти странные звуки. Демонстрирует изображение: три пуговицы на фоне нот пьесы Х. Кармайкла «Звездная пыль» (H. Carmichael. «Star Dust»). Попробуй расшифровать это послание.

В рисунке, на который ты смотришь, есть подсказки: послание инопланетян разделено остановками. Оно короткое. Напоминает нашу речь, но отличается от нее... Попробуй объяснить смысл послания, чтобы оно стало понятно землянам». Задает вопрос: «Какие звуки потребуются для инопланетной речи?» (Примерный ответ: «Пение, прищелкивание языком (демонстрирует), шумные вздохи, звуки из английского языка - th, w...»)

Наблюдает за творческим процессом. Отмечает в диагностической карте:

- наличие действий ребенка по созданию музыкально-речевой арт-композиции («ДА», «НЕТ»);

- использовал ли ребенок: интонационные «высказывания» (слитные, разделенные на слоги или «слова»), пение, рифмы, ритмически организованный поэтический текст, разнообразие интонаций, варьирование (ритмическое, темповое, штриховое), изменение динамики (громкости) голоса, жесты и мимику, танцевальные движения, элементы изобразительного и декоративно-прикладного искусства, другое;

- завершена или нет арт-композиция.

Если в процессе творчества ребенок использует речь в сочетании с пением, музыкальными и немузыкальные звучаниями, то делается отметка о проявлении дуовекторной - музыкально-лингвистической - одаренности.

Критерии оценки уровня выполнения задания (деятельности ребенка):

музыкальная одаренность

- высокий уровень (3 балла) - демонстрирует интерес к возможностям озвучить изображение с помощью музыки и немузыкальных звуков, речевых интонаций; самостоятельно создает музыкальноречевую арт-композицию - «речь» инопланетянина; использует разнообразный звуковой материал - возгласы, пение, рифмованные слова, ритмически организует высказывание; интонации «речи» разнообразны, варьируются ритмически, по темпу, штрихам, громкости; использует жесты, мимику, танцевальные движения, элементы изобразительного и декоративно-прикладного искусства; арт-композиция завершена по форме, компактна;

- средний уровень (2 балла) - демонстрирует интерес к возможностям озвучивания изображений с помощь музыки и немузыкальных звуков, речевых интонаций; с небольшой помощью педагога создает музыкально-речевую арт-композицию - «речь» инопланетянина; звуковой материал включает в основном пение и речь, объединенные ритмом; интонации «речи» варьируются; использованы некоторые элементы танца; арт-композиция не вполне завершена по форме, ее временные рамки расширены более, чем этого требует выразительность;

- низкий уровень (1 балл) - демонстрирует слабо выраженный интерес к взаимосвязи музыки и речи, озвучиванию изображений; для создания музыкально-речевой арт-композиции требуется постоянная помощь педагога; звуковой материал включает или пение, или речь, ритмическая основа выражена не отчетливо; интонации «речи» однообразны; другие виды искусства не используются; арт-композиция не завершена по форме, «бесконечна»;

- невыполнение задания оценивается в 0 баллов.

лингвистическая одаренность

- высокий уровень (3 балла) - внимателен к демонстрирует интерес к смысловому содержанию интонаций, их поиску в композиции, элементах изображения; использует русские и иностранные слова в их правильном значении; демонстрирует умение передавать смысл высказывания с использованием всех доступных выразительных средств; проявляет способность находить общие признаки явлений, на первый взгляд непохожих между собой; интуитивно находит наилучшие звуковые аналогии для передачи смысла изображения;

- средний уровень (2 балла) - демонстрирует интерес к смысловому содержанию интонаций, их поиску в композиции, элементах изображения; почти все русские и иностранные слова использует в правильном значении; совершает 1-2 ошибки в процессе передачи смысла высказывания с использованием доступных выразительных средств; с помощью педагога находит общие признаки явлений, на первый взгляд непохожих между собой; с подсказкой находит звуковые аналогии для передачи смысла изображения;

- низкий уровень (1 балл) - мало заинтересован поиском смыслового содержания интонаций, возможностью их «зашифрованного» изображения; ряд слов использует в неправильном значении; совершает 3 и более ошибок в процессе передачи смысла высказывания с использованием доступных выразительных средств; для нахождения общих признаков явлений требуется значительная помощь педагога; даже с подсказкой находит неудачные звуковые аналогии для передачи смысла изображения;

- невыполнение задания оценивается в 0 баллов.

Самарский научный вестник. 2018. Т. 7, № 4 (25) 
Калинина Л.Ю., Иванов Д.В.

Методика «Искусство+» была апробирована в модельных условиях на занятиях по программе курсов повышения квалификации для учителей музыки и изобразительного искусства (Самара, 2012-2018 гг.), в Центре внешкольного образования «Творчество» и в Детской школе искусств № 5 города Самары.

Материалы исследования представлены на международных конференциях в г. Казани (2018 г.) и г. Флоренция, Италия (2018 г.). Обсуждение позволило уточнить такие аспекты нашей работы, как:

- создание оценочных моделей, в связи с высокой индивидуализацией оценок арт-продуктов педагогами, участвующими в апробации методики «Искусство $+\gg ;$

- создание визуальных моделей-образцов для педагогов, иллюстрирующих «ризоматическое» творчество ребенка;

- определение преимуществ разных видов искусства в стимулировании проявлений одаренности 6-7летними детьми.

Таким образом, мы рассмотрели новый аспект понятия «одаренность» - взаимосвязь ее видов и теоретически обосновали гипотезу о существовании «дуовекторной» одаренности, проявляемой ребенком в процессе художественного творчества по созданию композиций-ризом в обогащенной образовательной среде.

В ряде следующих публикаций мы осветим результаты апробации методики «Искусство+», eе peпрезентативность, надежность и валидность.

Авторы благодарят руководство и педагогов Центра внешкольного образования «Творчество», Детской школь искусств № 5 городского округа Самара, менеджера по грантам научно-исследовательской части Самарского государственного соииально-педагогического университета Никитина Николая Александровича за оказанную поддержку, иенные рекомендации при планировании исследования $u$ рекомендации по оформлению статьи.

\section{Список литературы:}

1. Профессиональный стандарт «Педагог дополнительного образования детей и взрослых» [Электронный pecypc] // http://consultant.ru/document/ cons_doc_LAW_305809.

2. Профессиональный стандарт «Педагог» (педагогическая деятельность в сфере дошкольного, начального общего, основного общего, среднего общего образования) (воспитатель, учитель) [Электронный ресурс] // http://consultant.ru/document/cons_ doc_LAW_155553/.

3. Guilford J.P. The nature of human intelligence. N.Y.: Scribner, 1967. 538 p.

4. Renzulli J.S. What makes giftedness? Reexamining a definition // Phi Delta Kappan. 1978. Vol. 60 (3). P. 180-261.

5. Heller K.A. The Munich model of giftedness and its impact on identification and programming // Gifted and Talented International. 2005. P. 20-36.

6. Renzulli J.S., Gaesser A.H. Monograph for Critical Issues in Gifted Ed \& Talent Development A Multi Criteria System For the Identification of High Achieving and Creative/Productive Giftedness // Full-text Article. Apr 2015. Revista de Educación (Madrid).
7. Field G.B. The effects of using Renzulli Learning on student achievement: An investigation of internet technology on reading fluency, comprehension, and social studies. International Journal of Emerging Technology, 2009. № 4. P. 29-39.

8. Renzulli J.S., Reis S.M. The Schoolwide Enrichment Model: A how-to guide for educational excellence (3rd ed.) Waco, TX: Prufrock Press, 2014.

9. Feldhusen J.F., Hoover S.M. A conception of giftedness: intelligence, self concept and motivation. Roeper Review. 1986. № 8 (3). P. 140-143.

10. Mönks F.J., Ypenburg I.H. Hoogbegaafde kinderen thuis en op school. Alphen aan den Rijn: Samsom H.D. Tjeenk Willink, 1995.

11. Бабаева Ю.Д. Динамическая теория одаренности // Основные современные концепции творчества и одаренности / под ред. проф. Д.Б. Богоявленской. М.: Молодая гвардия, 1997. С. 275-295.

12. Савенков А.И. Развитие детской одаренности в образовательной среде // Развитие личности. 2002. № 3. С. 113-146.

13. Психология одаренности детей и подростков / под ред. Н.С. Лейтеса. М.: Издательский центр «Академия», 1996. 416 с.

14. Богоявленская Д.Б., Шадриков В.Д. и др. Рабочая концепция одаренности. 2-е изд., расш. и перераб. М., 2003.95 c.

15. Horowitz F.D. A developmental view of giftedness / S.M. Reis, R.J. Sternberg (Eds.) // Definitions and conceptions of giftedness. Thousand Oaks CA: Corwin Press. 2004. P. 145-154.

16. Kaufman S.B., Sternberg R.J. Conceptions of giftedness / S.I. Pfeiffer (Ed.) // Handbook of giftedness in children; Psycho-educational theory, research and best Practices. New York: Springer. 2008. P. 71-92.

17. Balchin T. The future of the English definition of giftedness // The routledge international companion to gifted education / Eds. T. Balchin, B. Hymer, D.J. Mathews. London: Routledge. 2009. P. 50-55.

18. Dai D.Y. The nature and nurture of giftedness: a new framework for understanding gifted education. New York: Teachers College, Columbia University, 2010.

19. Кац Е.Б. Психофизиологические и психологические особенности учащихся с признаками одаренности: дис. ... канд. психол. наук. Ростов-на-Дону, 2010. 165 c.

20. Gardner H. Intelligence Reframed. Multiple intelligences for the 21st century. New York: Basic Books. 1999. 292 p.

21. Matthews D.J., Folsom C. Making connections: cognition, emotion and a shifting paradigm / T. Balchin, B. Hymer, D.J. Matthews (Eds.) // The Routledge international companion to gifted education. London: Routledge. 2009. P. 18-25.

22. Туник Е.Е. Диагностика креативности. Тест Е. Торренса. СПб.: Иматон, 1998. 170 с.

23. Drake J.E., Winner E. Children gifted in drawing: The incidence of precocious realism // Gifted Education International. 2012. Vol. 29, is. 2. P. 125-139.

24. Гуткина Н.И. Методика «Домик»: описание, анализ результатов, выводы [Электронный ресурс] http://fb.ru/article/236410/gutkina-n-i-metodika-domikopisanie-analiz-rezultatov-vyivodyi.

25. Богданова И. Как оценить двигательные способности? Тесты для детей школьного возраста // 
Спорт в школе. 2001. № 8 [Электронный ресурс] // http://spo.1september.ru/article.php?ID=200100807.

26. Бриль М.С. Отбор в спортивных играх. М.: Физкультура и спорт, 1980.127 с.

27. Анисимов В.П. Диагностика музыкальных способностей. М.: ВЛАДОС, 2004. 130 с.

28. Диагностика уровня вербального (словесного) мышления 6-летних детей: [Электронный ресурс] // https://www.baby.ru/community/view/44180/forum/post /12522840.

29. Методика «МЭДИС» [Электронный ресурс] // http://cdk-detstvo.centerstart.ru/sites/cdk-detstvo.centerstart. ru/files/uroven_intellektualnogo_razvitiya_medis.pdf.

30. Ericsson K.A. Creative genius: A view from the expert-performance approach // D.K. Simonton (Ed.), The Wiley-Blackwell handbook of genius. New York: Wiley, 2014. P. 321-349

31. Ericsson K.A., Nandagopal K., Roring R.W. An expert-performance approach to the study of giftedness // L. Shavinina (Ed.), International handbook of giftedness. Berlin: Springer Science + Business Media. 2009. P. $129-153$

32. Адаскина А.А. Особенности проявления эстетического отношения при восприятии действительности // Вопросы психологии. 1999. №6. С. 100-110.

33. Никитин А.А. Развитие детской художественной одаренности в условиях дополнительного образования: дис. ... д-ра пед. наук. М., 2013. 391 с.

34. Мелик-Пашаев А.А., Новлянская 3.Н., Адаскина А.А., Чубук Н.Ф. Художественная одаренность детей, ее выявление и развитие. М.: Феникс, 2006. $112 \mathrm{c}$.

35. Кирнарская Д.К. Психология специальных способностей. Музыкальные способности. М.: Таланты - XXI век, 2004. 496 с.

36. Тестов В.А. Математическая одаренность и ее развитие // Perspectives of Science and Education, 2014, № 6 (12). C. 60-67.

37. Соколик И.Ю. Организационно-методические основы диагностики спортивной одаренности: дис. ... д-ра пед. наук. Мн., 1998. 357 с.

38. Сальников В.А. Особенности межпризнаковых и межвозрастных связей показателей морфофункционального развития // Индивидуальные и возрастные особенности развития двигательных и умственных способностей: сб. науч. тр. Омск, СибАДИ. 2010. $196 \mathrm{c.}$

39. Панфилова В.М. Психолого-педагогические условия формирования иноязычной компетентности лингвистически одаренных студентов неязыкового вуза: дис. ... канд. пед. наук. Йошкар-Ола, 2016. $195 \mathrm{c}$.

40. Winner E., Martino G. Giftedness in the visual arts and music // Heller K., Monks F. and Passow A.H. (eds.) International Handbook of Research and Development of Giftedness and Talent. NewYork: Pergamon, 1993. P. 253-281.

41. Kirnarskaya D., Winner E. Musical Ability in a New Key: Exploring the Expressive Ear for Music. Psychomusicology. 1999.

42. Столяр А.А. Педагогика математики. Мн.: Вышейшая школа, 1974. 382 с.

43. Никитин А.А. Интеллект и художественное мышление. Хабаровск: ХГИИК, 2007. 120 с.
44. Гингулис Э.Ж. Системный подход в исследовании математических способностей учащихся // Математическое образование: концепции, методики, технологии: сборник трудов IV междунар. науч. конф. «Математика. Образование. Культура». Ч. 2. Тольятти: ТГУ. 2009. С. 88-92.

45. Сафроненко Е.Ф. Экспериментальное исследование способностей к изобразительной деятельности у детей старшего дошкольного возраста // Вестник Томского государственного педагогического университета. 2011. Вып. 10 (112). С. 102-106.

46. Gardner H. Multiple Intelligences; The Theory in Practice. New York: Basic Books, 1993. P. 9-11.

47. Rankinen T., Bouchard C. Dose-response issues concerning the relationship between regular physical activity and health. President's Councilon Physical Fitnessand Sports Research Digest. 2002. № 3 (18). P. 3-10.

48. Игна О.Н. «Слагаемые» лингвистической одаренности и способностей к иностранным языкам // Актуальные проблемы линводидактики, лингвокультурологии и межкультурной коммуникации // Вестник Томского государственного педагогического университета. 2012. Вып. 10 (125). С. 109-113.

49. Takahashi M. Earthquake disaster and the potential of adult art education: the significance of holistic learning // SGEM international multidisciplinary scientific conference on social sciences and art. 2018. STEP92 Technology Ltd., 51 «Alexander Malinov» Blvd., 1712 Sofia, Bulgaria. P. 133-144.

50. Eco U. Opera aperta. Milano: Bompiani, 1962. $370 \mathrm{p}$.

51. Делез Ж., Гваттари Ф. Ризома // Философия постмодерна. Минск: Беларусь, 1996. С. 10-12.

52. Ceplitis A. Rhizomatic narratology in 360 degree spherical cinematography // International Multidisciplinary Scientific Conference on Social Sciences and Arts, Vol. 4, 2016.

53. Ceplitis A. The Tension of Embodiment and Narrative Taxonomy in 360 Degree Spherical 3D Setting // RIXC Art Science Festival, 2017, Riga.

54. Сокрута Е.Ю. Нарративные характеристики новостного дискурса в эпоху новой медиальности // Новый филологический вестник. 2018. № 2 (45). C. $39-46$.

55. Маньковская Н.Б. Постмодернизм в эстетике // Философская антропология. 2018. Т. 4, № 1. C. $192-230$.

56. Елкина И.М. О новых дидактических концептах: ризомоподобное обучение // Перспективы отечественного образования. 2016. № 11. С. 82-95.

57. Калинина Л.Ю. Арт-композиция как маркер музыкальной одаренности старших дошкольников: к постановке проблемы // Современное дошкольное образование. 2018. № 6 (88). С. 43-49.

58. Kalinina L., Ivanov D. Early identification of giftedness in the art creativity process // SGEM international multidisciplinary scientific conference on social sciences and art. 2018. STEP92 Technology Ltd., 51 «Alexander Malinov» Blvd., 1712 Sofia, Bulgaria. P. 125-132.

Исследование выполнено при финансовой поддержке РФФИ в рамках научного проекта № 18413-630003.

Самарский научный вестник. 2018. Т. 7, № 4 (25) 


\title{
THE IDENTIFICATION METHOD OF 6-7 YEAR-OLD-CHILDREN’S «DUOVECTOR» GIFTEDNESS IN THE ART-CREATIVITY PROCESS
}

\author{
(C) 2018 \\ Kalinina Larisa Yuryevna, candidate of pedagogical sciences, leading researcher of Research Department \\ Ivanov Dmitriy Victorovich, candidate of psychological sciences, \\ associate professor of Pedagogy and Psychology Department \\ Samara State University of Social Sciences and Education (Samara, Russian Federation)
}

\begin{abstract}
The paper deals with one of the aspects of early identification of giftedness: the establishment of the relationship between its types. The authors see a solution of the problem in the development and validation of the methodology based on the integrated modern scientific knowledge - psychological, pedagogical and art criticism, in the field of contemporary art. This technique is expected to meet the conditions of efficiency and accessibility in the application of teachers working with children. Clarifications have been made to the basic concept of «giftedness» for the paper. The authors propose a term describing the interrelated manifestation of two types of giftedness - «duovector» talent. The method is aimed at finding hidden signs of «duovector» giftedness: musical mathematics, in the field of fine art and sports, musical and linguistic. The basis of this approach is the idea of the dependence of the frequency and brightness of giftedness manifestations on the conditions, the most important of which is the aesthetic environment enriched with multi-modal material for creativity. At the same time, it is advisable to involve children in accessible and aesthetically valuable works of modern art, in the search for new knowledge in the same ways that adult authors of the XXI century use. Modeling directly perceived creative techniques and forms, the child masters the world, structures it non-linearly, on the principle of creating a rhizome. As a «catalyst» of creative activity, a set of tasks-subtests adapted to the age peculiarities of children is offered. The procedure of the experiment in a specially organized educational environment (an art workshop) is characterized. Plunging into the atmosphere of «fruitful disorder», the child will act freely and directly, engaged in creativity as a game, creates an art product that has value as a marker of his talent. The content of creative tasks is presented, according to the results of work on which the diagnostic card is filled, in turn, which is the basis for the conclusions about the presence of the child's «duovector» talent. At this stage of the study, the authors have prepared a method for validation by comparing it with tests and subtests of other methods. The materials of the paper logically continue the research in the field of finding reference points for the development of individual educational routes of students, preparing them for lifelong learning.

Keywords: giftedness; gifted children; education; creativity of child; synthesis of arts; educational artistic and creative activity; rhizome; senior preschoolers; first-graders; art workshop; individual educational trajectory; contemporary art; art composition.
\end{abstract}

УДК 378.147.001.572:51

DOI $10.24411 / 2309-4370-2018-14309$

Статья поступила в редакцию 19.08.2018

(C) 2018

\section{ВЕКТОРНАЯ ИНТЕРПРЕТАЦИЯ ОЦЕНКИ ОСТАТОЧНЫХ ЗНАНИЙ ОБУЧАЮЩИХСЯ}

\author{
Макаров Сергей Иванович, доктор педагогических наук, \\ заведующий кафедрой высшей математики и экономико-математических методов \\ Севастьянова Светлана Александровна, кандидат педагогических наук, \\ доцент кафедры высшей математики и экономико-математических методов \\ Самарский государственный экономический университет (г. Самара, Российская Федераџия)
}

Аннотация. Контроль остаточных знаний - одна из процедур, используемых в системе образования России для мониторинга качества образования на различных уровнях. Как правило, эта процедура реализуется в форме компьютерного тестирования по изученным ранее дисциплинам. Анализ результатов тестирования дает основание для принятия решений о выполнении коррекционных мероприятий. Это определяет важность задачи достоверного, доступного и информативного представления результатов мониторинга. В статье предложен метод визуализации и интерпретации результатов контроля остаточных знаний, обоснована возможность его использования в целях анализа проблем обучения на индивидуальном и групповом уровнях. Предложено использовать для обработки статистической информации векторную форму представления совокупности данных. В этом случае визуализация результатов контроля имеет вид пространственного вектора или развертки многомерного вектора на плоскость. Обсуждаются возможности визуальной оценки достижения пороговых значений уровня знаний. Приведены примеры использования векторной модели для оценки уровня остаточных знаний по трем и более дисциплинам. Предложен подход к решению вопроса о сопоставимости результатов тестирований, проведенных в различных системах оценивания. Основные выводы и результаты могут быть использованы непосредственно в учебном процессе, в сфере управления образованием, в психолого-педагогической работе.

Ключевые слова: математические методы в педагогике; педагогическая диагностика; результаты тестирования; контроль остаточных знаний; обработка данных мониторинга; оценка знаний; математическая обработка результатов тестирования; визуальная интерпретация оценки знаний; лепестковая диаграмма. 